University of Nebraska - Lincoln

DigitalCommons@University of Nebraska - Lincoln

Publications from USDA-ARS / UNL Faculty

U.S. Department of Agriculture: Agricultural

Research Service, Lincoln, Nebraska

2017

\title{
A nano particle vector comprised of poly lactic-co-glycolic acid and monophosphoryl lipid $A$ and recombinant Mycobacterium avium subsp paratuberculosis peptides stimulate a pro-immune profile in bovine macrophages
}

\author{
C.D. Souza \\ Washington State University, Pullman, souza@vetmed.wsu.edu \\ John Bannantine \\ USDA ARS National Animal Disease Center, john.bannantine@usda.gov \\ W.C. Brown \\ Washington State University, Pullman \\ M.G. Norton \\ Washington State University, Pullman \\ W.C. Davis \\ Washington State University, Pullman \\ Follow this and additional works at: https://digitalcommons.unl.edu/usdaarsfacpub \\ Part of the Agriculture Commons \\ See next page for additional authors
}

Souza, C.D.; Bannantine, John; Brown, W.C.; Norton, M.G.; Davis, W.C.; Hwang, J.K.; Ziaei, P.; Abdellrazeq, Gaber S.; Eren, M.V.; Deringer, J.R.; Laws, E.; and Cardieri, M.C.D., "A nano particle vector comprised of poly lactic-co-glycolic acid and monophosphoryl lipid A and recombinant Mycobacterium avium subsp paratuberculosis peptides stimulate a pro-immune profile in bovine macrophages" (2017). Publications from USDA-ARS / UNL Faculty. 2407.

https://digitalcommons.unl.edu/usdaarsfacpub/2407

This Article is brought to you for free and open access by the U.S. Department of Agriculture: Agricultural Research Service, Lincoln, Nebraska at DigitalCommons@University of Nebraska - Lincoln. It has been accepted for inclusion in Publications from USDA-ARS / UNL Faculty by an authorized administrator of DigitalCommons@University of Nebraska - Lincoln. 


\section{Authors}

C.D. Souza, John Bannantine, W.C. Brown, M.G. Norton, W.C. Davis, J.K. Hwang, P. Ziaei, Gaber S. Abdellrazeq, M.V. Eren, J.R. Deringer, E. Laws, and M.C.D. Cardieri 


\title{
A nano particle vector comprised of poly lactic-co-glycolic acid and monophosphoryl lipid A and recombinant Mycobacterium avium subsp paratuberculosis peptides stimulate a pro-immune profile in bovine macrophages
}

\author{
C.D. Souza1, J.P. Bannantine², W.C. Brown ${ }^{3}$, M.G. Norton ${ }^{3}$, W.C. Davis ${ }^{4}$, J.K. Hwang ${ }^{1}$, P. Ziaei ${ }^{3}$, \\ G.S. Abdellrazeq ${ }^{4,5}$ (D) M.V. Eren ${ }^{1}$, J.R. Deringer ${ }^{3}$, E. Laws $^{1}$ and M.C.D. Cardieri ${ }^{1}$ \\ 1 Department of Veterinary Clinical Sciences, College of Veterinary Medicine, Washington State University, Pullman, WA, USA \\ 2 National Animal Disease Center, USDA-Agricultural Research Service, Ames, IA, USA \\ 3 School of Mechanical and Materials Engineering, Washington State University, Pullman, WA, USA \\ 4 Department of Veterinary Microbiology and Pathology, Washington State University, Pullman, WA, USA \\ 5 Department of Microbiology, Faculty of Veterinary Medicine, Alexandria University, Alexandria, Egypt
}

\section{Keywords}

Anaplasma marginale, monophosphoryl lipid

A, Mycobacterium avium subsp.

paratuberculosis, peptide vaccine, PLGA.

\section{Correspondence}

Cleverson D. Souza, Department of Veterinary

Clinical Sciences, College of Veterinary

Medicine, Washington State University,

Pullman 99164, WA, USA

E-mail: souza@vetmed.wsu.edu

2017/0386: received 27 February 2017, revised 19 April 2017 and accepted 9 May 2017

doi:10.1111/jam.13491

\begin{abstract}
Aims: We evaluated the potential of a nanoparticle (NP) delivery system to improve methods of delivery of candidate peptide-based vaccines for Paratuberculosis in cattle.

Methods and Results: Peptides derived from Mycobacterium avium subsp. paratuberculosis (Map), and the pro-inflammatory monophosphoryl lipid A (MPLA) were incorporated in polymeric NPs based on poly (D,L-lactide-coglycolide) (PLGA). The PLGA/MPLA NPs carriers were incubated with macrophages to examine their effects on survival and function. PLGA/MPLA NPs, with and without Map antigens, are efficiently phagocytized by macrophages with no evidence of toxicity. PLGA/MPLA NP formulations did not alter the level of expression of MHC I or II molecules. Expression of TNF $\alpha$ and IL12p40 was increased in Map-loaded NPs. T-cell proliferation studies using a model peptide from Anaplasma marginale demonstrated that a CD4 Tcell recall response could be elicited with macrophages pulsed with the peptide encapsulated in the PLGA/MPLA NP.

Conclusions: These findings indicate PLGA/MPLA NPs can be used as a vehicle for delivery and testing of candidate peptide-based vaccines.

Significance and Impact of the Study: These results will assist on more in depth studies on PLGA NP delivery systems that may lead to the development of a peptide-based vaccine for cattle.
\end{abstract}

\section{Introduction}

Paratuberculosis is a costly, chronic, progressive granulomatous disease of the small intestine of ruminants caused by Mycobacterium avium subsp. paratuberculosis (Map), with high prevalence in US dairy herds (Harris and Barletta 2001). Control programmes for paratuberculosis have been impeded by an incomplete understanding of the immune response to Map and the lack of a vaccine that induces protective immunity (Harris and Barletta 2001; Chen et al. 2012; Settles et al. 2014; Bannantine and Talaat 2015). Attempts to develop more efficient vaccines against Map have not been successful (Bannantine and Talaat 2015; Bannantine et al. 2014). Commercial vaccines available for ruminants reduce production losses, mortality, histopathological lesions (Wentink et al. 1994; Griffin et al. 2009), bacterial shedding (Kormendy 1994) and extend the productive life of vaccinated animals, but 
do not provide complete protection from infection (Reddacliff et al. 2006; Bannantine and Talaat 2015). Moreover, the use of a killed or live attenuated vaccine is limited mainly to sheep due to the cross-reaction it produces with the immunological diagnosis of bovine tuberculosis in cattle (Stringer et al. 2011). The research highlighted above emphasizes the need to explore development and testing of new candidate vaccines for efficacy.

Recent studies with a Map relA deletion mutant suggest it might be possible to develop a peptide-based vaccine (Park et al. 2014). Deletion of relA, a global gene regulator, disrupts the capacity of Map to establish a persistent infection indicating that the response directed towards one or more Map proteins is sufficient to block the establishment of a persistent infection. Identification of which proteins account for blocking development of persistent infection could lead to the development of a peptide-based vaccine. Such a vaccine would clearly have advantages over killed and live attenuated mutant vaccines in terms of feasibility for large-scale commercial production, and human safety. As mentioned, one of the impediments in developing peptide-based vaccines has been identifying a delivery system that protects and optimizes delivery of peptides to antigen presenting cells (APC) through pattern recognition receptors (PRRs) that modulate the expression of cytokines that drive differentiation of $\mathrm{T}$ cells with different effector activity. The objective of the present study was to evaluate a novel delivery system for its potential use in next-generation vaccines for Paratuberculosis, and other pathogens affecting the livestock industry.

Poly lactic-co-glycolic acid (PLGA) is a safety polymer with diverse formulations available commercially and approved by health regulatory agencies (Danhier et al. 2012). PLGA NPs have been shown to boost immune responses in several animal models (Elamanchili et al. 2007; Klippstein and Pozo 2010; Hamdy et al. 2011; Danhier et al. 2012). For example, enhanced immune responses to entrapped antigens were observed in mice following oral administration of PLGA NPs. These findings were considered to be a consequence of their uptake into $M$ cells, and their ability to stimulate APC in Peyer's patches in the intestines (Eldridge et al. 1992). PLGA NPs polarize immune responses from predominantly antibody- and Th2-type responses to the more protective Th1-type responses (Conway et al. 2001), and also facilitate the induction of CD8 cytotoxic T lymphocytes in several disease models (Conway et al. 2001; Chong et al. 2005; Elamanchili et al. 2007). Depending on the goal, an extensive variety of particle sizes with unique physicochemical characteristics, antigen load and release profiles can be formulated using PLGA. Studies have shown that $300 \mathrm{~nm}$ to $2 \mu \mathrm{m}$ NPs are readily phagocytized by macrophages (Elamanchili et al. 2007; Hamdy et al. 2011; Danhier et al. 2012). Importantly, as biochemically distinct molecules can be encapsulated in PLGA NPs, a wide variety of adjuvants can be incorporated in the same PLGA NP formulation, thereby increasing the effectiveness of the vaccine (Chong et al. 2005; Elamanchili et al. 2007; Klippstein and Pozo 2010; Hamdy et al. 2011).

Monophosphoryl lipid A (MPLA) is a commercially available endotoxin derivative that has been used as a vaccine adjuvant (Ulrich and Myers 1995; Kathaperumal et al. 2008; Fichter et al. 2015). MPLA is produced by the hydrolysis of native diphosphoryl lipid $\mathrm{A}$, the component of LPS that is recognized specifically by the pro-inflammatory receptor TLR4 (Wang 2013). The structural alterations that occur during this process (i.e. removal of all but a single phosphate group; deacylation) decrease systemic toxicity by $>99 \%$ when compared to native bacterial LPS. This results in an immunomodulatory agent with greater potential for clinical use (Wang 2013; Cui et al. 2014; Fichter et al. 2015). The attenuated toxicity of MPLA is associated with reduced induction of pro-inflammatory cytokines such as TNF $\alpha$, IL1 $\beta$ and IFN $\gamma$ during initial exposure. Despite this, MPLA retains significant immunomodulatory activity and prior treatment with MPLA increases survival after otherwise lethal exposure to LPS in animal models (Wang 2013; Cui et al. 2014; Fichter et al. 2015).

One question that had to be addressed at the outset of this study was which Map protein should be encapsulated into the NPs. We restricted our selection to lipoproteins because they have been shown to interact with the TLR2 pathway (Noss et al. 2001; Bowdish et al. 2009). By measuring cytokine proliferation in response to 42 Map lipoproteins, we identified two protein candidates (MAP2322c and MAP0981c) that induced high levels of the immune-modulatory cytokine IL12 and the proinflammatory cytokine TNF $\alpha$, while inducing low levels of the anti-inflammatory protein IL10 (Bannantine et al. 2015). These two proteins were incorporated into NPs for this study.

As described herein, examination of the methods of construction and functional activity of MPLA/PLGA NP as vectors for delivery of peptide-based vaccines have shown PLGA NPs are a good choice as a delivery system for peptide-based vaccines for Paratuberculosis, Anaplasmosis and other pathogens of ruminants.

\section{Materials and methods}

\section{Bovine monocyte isolation and in vitro macrophage generation}

The study was carried out in accordance with the recommendations, institutional guidelines and approved Animal 
Care and Use Committee (IACUC) protocols (\#04543003) at Washington State University. Peripheral blood used for monocyte isolation were collected from healthy adult Holstein dairy cows that tested negative for paratuberculosis as determined by faecal culture and polymerase chain reaction (PCR) assays of blood and faecal samples. Isolation and generation of bovine macrophages was carried out as previously described (Souza 2015). Briefly, peripheral blood mononuclear cells (PBMC) were isolated by centrifugation on a Percoll (Sigma-Aldrich, St. Louis, MO, USA) density gradient. Briefly, blood was layered onto 50-ml conical tubes containing Histopaque 1077 (Sigma-Aldrich), and following density gradient centrifugation (500 $g$ for $20 \mathrm{~min}$ ) at room temperature, PBMC were collected. The PBMC were washed twice with sterile phosphate-buffered saline (PBS; Invitrogen ${ }^{\mathrm{TM}}$; ThermoFisher Scientific, Waltham, MA, USA) before being resuspended in PBS. Monocytes were then isolated using microbeads conjugated to a cross-reactive mouse antihuman CD14 Mab (Miltenyi Biotec Ltd, San Diego, CA). The isolation was performed according to the manufacturers' instructions. The identity and purity of monocytes was $>95 \%$ as determined by flow cytometry using an anti-CD14 fluorescein-labelled antibody as described (Souza 2015). Purified monocytes were seeded at $1 \times 10^{6}$ per well on standard 24-well tissue culture plates containing RPMI 1640 medium (Invitrogen, Life Technologies Corporation) containing $10 \%$ heat-inactivated FBS (Sigma-Aldrich), gentamicin $\left(5 \mathrm{~g} \mathrm{l}^{-1}\right.$; Sigma-Aldrich), $100 \mu \mathrm{g}^{-1}$ of bovine-specific GM-CSF (Kingfisher, St. Paul, MN, USA) and $1 \mathrm{~mol} \mathrm{l}^{-1} \beta$-mercaptoethanol. Subsequently, cells were incubated at $37^{\circ} \mathrm{C}$ and $5 \% \mathrm{CO}_{2}$. On Day 7, confluent monolayers of MoM $\Phi$ displayed the characteristic macrophage morphology as confirmed by light microscopy and expected immunophenotype. Thereafter, МоMФ were used for the in vitro challenge experiments with PLGA NPs formulations.

\section{Production and purification of recombinant Map proteins}

Recent evidence suggests that Map proteins play key roles in the host-immune responses to Map (Souza et al. 2013), and many vaccine trial studies using Map proteins as immunogens have shown promise (Rigden et al. 2006; Kathaperumal et al. 2008, 2009; Roupie et al. 2008). We therefore screened a large number of Map proteins annotated as lipoproteins to test in our in vitro macrophage model. These proteins were recombinantly expressed in Escherichia coli and purified by affinity chromatography (Bannantine et al. 2015). Briefly, Map genes annotated as lipoproteins (MAP2322c and MAP0981c), along with several control proteins were cloned into the pMAL-c $2 x$ expression vector and transformed into E. coli DH5. All clones were confirmed to be correct and in-frame with the maltose-binding protein by DNA sequencing. Confirmed transformants were cultured, induced with isopropyl $\beta$-D-1-thiogalactopyranoside (IPTG), and purified as described previously (Bannantine et al. 2010). The only modification was that proteins eluted off the amylose resin column were collected and loaded onto a second amylose column to maximize removal of potential LPS contamination. These proteins were expected to be nonlipidated and were used for the PLGA NP synthesis.

\section{Synthesis of PLGA NP formulations}

PLGA NPs were formulated to internally carry one of five different proteins at $10 \% \mathrm{w} / \mathrm{v}$ : MAP0981c, MAP2322c, OVA, OVA-FITC or Anaplasma marginale outer membrane (OM)-derived peptides, VirB9-2 P5, or VirB9-1 P8 (which were gifts from Dr Brown, Washington State University. Externally PLGA NPs were loaded with MPLA at $1 \% \mathrm{w} / \mathrm{v}$. PLGA NPs were generated using the double emulsion water-in-oil-in-water $(\mathrm{w} / \mathrm{o} / \mathrm{w})$ technique as previously described by our group (Guldner et al. 2016a). Briefly, $9 \mathrm{~g} \mathrm{l}^{-1}$ of PLGA 75:25 (PolySciTech ${ }^{\circledR}$, IN) at a molecular weight of 25-35 kDa were dissolved in $450 \mu \mathrm{l}$ of chloroform; $50 \mu \mathrm{l}$ of PBS was then added to create a water-in-oil (w/o) emulsion. The resultant solution was emulsified by sonication twice for $30 \mathrm{~s}$ each on ice using a Branson Ultrasonics Sonifier ${ }^{\mathrm{TM}}$ Cup Horn sonicator at an amplitude of $20 \%$. This first emulsion was then added dropwise into $1 \mathrm{ml}$ of $1 \%$ poly vinyl alcohol (PVA) (Sigma Aldrich, St. Louis, MO, USA) at a molecular weight of 31$50 \mathrm{kDa}$, while the mixture was being continuously vortexed. Initially, $2.5 \mathrm{ml}$ of a PLGA chloroform solution $\left(60 \mathrm{~g} \mathrm{l}^{-1}\right.$ ) was mixed with $0 \cdot 1 \mathrm{ml}$ of a MPLA from S. Minnesota R595-TLR-based adjuvant vaccine grade ${ }^{\mathrm{TM}}$ (InvivoGen, San Diego, CA) solution $\left(20 \mathrm{~g} \mathrm{l}^{-1}\right)$ in methanol: chloroform $(1: 4 \mathrm{v} / \mathrm{v})$. Emulsion (w/o) was carry out by adding $0.5 \mathrm{ml}$ of $20 \mathrm{~g} \mathrm{l}^{-1}$ of the several peptides used in this study adjusted for the required concentration into the PLGA/MPLA recipe. A bath sonicator (Vibra Cell VC-505) at a $40 \%$ amplitude for $40 \mathrm{~s}$ was used for the emulsification step. Then, the emulsion (w/o) was added into a $12 \mathrm{ml}, 1 \% \mathrm{w} / \mathrm{v}$ PVA solution. The recipe was then sonicated at a $40 \%$ amplitude for $2 \mathrm{~min}$. The resulting emulsion was vortex overnight for proper solvent evaporation. The PLGA NPs were purified by means of four successive centrifugations at $5000 \mathrm{~g}$ and $4^{\circ} \mathrm{C}$ for 10 -min dispersion cycles, and were subsequently lyophilized. Empty and PLGA/MPLA NPs served as controls. PLGA NPs were then dispersed in a $9 \%(\mathrm{w} / \mathrm{v})$ sucrose solution $\left(10 \mathrm{~g} \mathrm{l}^{-1} \mathrm{NP}\right.$ per $\mathrm{ml}$ sucrose solution) followed by sterilization in a UV incubator for $10 \mathrm{~min}$ to $20 \mathrm{~min}$. 


\section{Determination of PLGA NP morphology}

The morphology of the PLGA NPs was determined by scanning electron microscopy (SEM). Briefly, dried PLGA/ MPLA preparations containing MAP2322c, MAP0981c or LPS-free OVA were applied onto a pin stub covered with double-sided carbon tape and then coated with $3 \cdot 5 \mathrm{~nm}$ of platinum/palladium using a Cressington Sputter Coater. Images were taken using an FEI Quanta 200F SEM (Franceschi Microscopy and Imaging Center, WSU, Pullman, WA) at $5-10 \mathrm{kV}$ accelerating voltage. The PLGA NPs preparation sizes were then measured using ImageJ software (NIH, Bethesda, MD, USA, 1.48v).

\section{Determination of PLGA NPs polydispersibility and zeta potential}

Polydispersibility and zeta potential were performed using Zetasizer nano ZS instrument and DTS software (Malvern Instruments, Worcestershire, UK). Briefly, the lyophilized PLGA NPs formulations contained in microcentrifuge tubes were suspended in PBS, $\mathrm{pH} 7.4$ and introduced into the instrument according to manufacture guidelines.

\section{Determination of MAP0981c, MAP2322c, OVA and MPLA encapsulation efficiency}

A protein assay kit (Pierce Biotechnology, Rockford, IL) was used for the quantification of protein loading in NP preparations (wt $\%$ ). Briefly, $2.5 \mathrm{~g} \mathrm{l}^{-1}$ of PLGA NPs were dissolved in $0.2 \mathrm{ml}$ of $0.1 \mathrm{~mol} \mathrm{l}^{-1} \mathrm{NaOH}$ solution. After overnight incubation at $4^{\circ} \mathrm{C}$, the protein concentration was measured using a BCA protein assay kit according to the manufacturer's instructions. Sample absorbance was measured at $562 \mathrm{~nm}$ by means of a microplate reader (BioTek, Winooski, VT). Empty PLGA NPs served as the control. Protein encapsulation efficiency (EE) is determined as the ratio of the protein content in the PLGA NPs divided by the total mass of protein used. A limulus amebocyte lysate (LAL) kit (ThermoFisher Scientific, Rockford, IL, USA) was used for the determination of the MPLA LC (wt\%) in the NPs. Accordingly, aqueous MPLA solutions were analysed with LAL in a plate reader to set up a calibration curve. The calibration curve for the MPLA concentration ranged from 0.01 to $10 \mu \mathrm{g} \mathrm{l}^{-1}$ with a calculated correlation coefficient of $R^{2}=0 \cdot 9$. MPLA content in the PLGA NPs was calculated by subtracting the concentration of supernatant-containing MPLA from the starting concentration of MPLA in the formula. MPLA EE was determined by the ratio of the measured MPLA concentration in the PLGA NPs to the total concentration of MPLA in the formula.
Intracellular uptake of PLGA NP preparations by bovine macrophages

MoMФ were incubated with $50 \mathrm{mg} \mathrm{l}^{-1}$ PLGA/MPLA alone or PLGA/MPLA NP containing LPS-free OVAFITC (EndoFit ${ }^{\mathrm{TM}}$; InvivoGen) for $24 \mathrm{~h}$. The cells were detached from the 12-well plates after a 10 min-incubation at $37^{\circ} \mathrm{C}$ with a prewarmed solution of $10 \mathrm{~mol} \mathrm{l}^{-1}$ EDTA containing 5\% FBS. After two washes, the cells were fixed with $2 \%$ paraformaldehyde containing $2 \%$ glutaraldehyde in $0 \cdot 1 \mathrm{~mol} \mathrm{l}^{-1} \mathrm{PBS}$ overnight at $4^{\circ} \mathrm{C}$. MoMФ were dehydrated with ethanol: acetone solution and embedded in resin. Sections were realized via a microtome (Leica Reichert Ultracut R Microtome, Franceschi Microscopy and Imaging Center, WSU). The sections were then placed on a nickel grid, followed by staining with $2 \%$ aqueous uranyl acetate. Analysis of the uptake of PLGA/MPLA OVA-FITC NPs by MoMФ was performed by transmission electron microscopy (TEM) (FEI Tecnai G2 20 Twin, Franceschi Microscopy and Imaging Center) at $200 \mathrm{kV}$.

Cellular uptake of PLGA/MPLA OVA-FITC NP was subsequently evaluated by confocal microscopy (Zeiss 510 META Confocal Laser Scanning Microscope, Franceschi Microscopy and Imaging Center). Briefly, MoMФ were cultured on coverslips in a six-well culture plastic plate and then incubated for $2 \mathrm{~h}$ with $50 \mathrm{mg} \mathrm{l}^{-1}$ of PLGA NPs formulations as described above. After cell culture medium removal, the cells were fixed with $2 \%$ paraformaldehyde for $10 \mathrm{~min}$ at $37^{\circ} \mathrm{C}$. The coverslips were rinsed with PBS and stained with a drop of ProLong ${ }^{\circledR}$ Gold antifade reagent with DAPI $\left(4^{\prime}, 6\right.$-diamidino-2-phenylindole) and evaluated by confocal microscopy. DAPI was excited with a diode laser $(405 \mathrm{~nm})$ and the emission was collected with a BP420-480 IR filter. FITC was excited with an argon laser at $488 \mathrm{~nm}$ and the emission was collected with BP505-570 IR filter. Multitracking was used to decrease interchannel cross-talk and confocal scanning parameters were set up for bright field background.

Further evaluation of phagocytosis was performed by flow cytometric analysis. Briefly, after 7 days of culture, $1 \times 10^{6}$ MoMФ per $\mathrm{ml}$ were treated with either PBS, $50 \mathrm{mg}^{-1}$ OVA-FITC or PLGA/MPLA OVA-FITC NP for $24 \mathrm{~h}$. Four wells of a standard 12-well plastic culture plate were assigned to each of these treatment groups. The cells were harvested using a sterile cell scraper, and thoroughly washed using $\mathrm{PBS}$ at $37^{\circ} \mathrm{C}$ to remove nonphagocytized PLGA NPs. Samples were analysed on a BD FACSCalibur and analysed using FCS Express 4 (DeNovo Software, Los Angeles, CA). Results were presented as histograms, with the macrophages incubated with PBS and an isotype Mab as a control for nonspecific binding. 


\section{Viability of bovine macrophage exposed to PLGA NP preparations}

MoMФ viability was evaluated by trypan blue exclusion assay and morphology by light microscopy. МoMФ were incubated with $50 \mathrm{mg} \mathrm{l}^{-1}$ of PLGA/MPLA NPs, $50 \mathrm{mg} \mathrm{l}^{-1}$ of PLGA/MPLA/MAP0981c or $50 \mathrm{mg} \mathrm{l}^{-1}$ of PLGA/MPLA/MAP2322c NPs for 2 or $24 \mathrm{~h}$. The adherent cells were harvested after incubation at $37^{\circ} \mathrm{C}$ with prewarmed solution of $10 \mathrm{~mol}^{-1}$ EDTA in 5\% PBS and mixed with trypan blue $(1: 10)$. The percentage of viable MoMФ (cells that did not take up trypan blue), was assessed in a haemocytometer chamber using light microscopy. Aliquots of $1 \times 10^{6} \mathrm{MoM} \Phi$ were further cytocentrifuged at $4000 \mathrm{~g}$ for $5 \mathrm{~min}$ (Cytospin ${ }^{\mathrm{TM}}$; ThermoFisher, Waltham, MA), and stained with a Wright's-based stain. Thereafter, macrophage morphology was evaluated by light microscopy for evidence of apoptosis or cell necrosis by a Board Certified Clinical Pathologist.

\section{Determination of TNF $\alpha$, IL12p40 and IL10 expression by qRT-PCR}

Seven-day-old bovine MoMФ were incubated with $50 \mathrm{mg} \mathrm{l}^{-1}$ of PLGA/MPLA NPs, $50 \mathrm{mg} \mathrm{l}^{-1}$ of PLGA/ MPLA/MAP0981c, $50 \mathrm{mg}^{-1}$ of PLGA/MPLA/MAP2322c NPs or $1 \mathrm{mg} \mathrm{l}^{-1}$ of LPS for $0,24,36$ or $72 \mathrm{~h}$. Total RNA was extracted from the treated cells using the Aurum ${ }^{\mathrm{TM}}$ Total RNA Mini Kit (BioRad, Hercules, CA) following the manufacturer's recommendations for cultured cells. The amount of total RNA was determined spectrophotometrically (NanoDrop ${ }^{\mathrm{TM}} 1000$ Spectrophotometer; Thermo Scientific, Waltham, MA). Reverse transcription of mRNA into cDNA was processed in accordance with the manufacturer's recommendations (iScriptTM Reverse Transcription Supermix for RT-qPCR; BioRad, Hercules, CA) to obtain a cDNA final volume of $20 \mu \mathrm{l}$ from $100 \mathrm{ng}$ of total RNA using a thermal cycler (Axygen ${ }^{\circledR}$ MaxyGeneTM II Thermal Cycler, Corning, NY). The cDNA product was amplified by PCR using validated primers designed by Qiagen RT2 qPCR Primer Assay as described (Souza 2015). Expression levels of GAPDH gene were used to normalize the input of cDNA. Realtime PCR was performed using Power SYBR Green PCR Master Mix (Applied Biosystems, Foster City, CA), following the manufacturer's recommendations. Briefly, each well contained a $20-\mu \mathrm{l}$ reaction mixture consisting of $10 \mu \mathrm{l}$ of the SYBR Green qPCR Master Mix, $4 \mu \mathrm{l}$ of water, $2 \mu \mathrm{l}$ of each specific primer set and $4 \mu \mathrm{l}$ of $1 / 20$ diluted cDNA template. The thermal profile settings consisted of a $10-\mathrm{min}$ denaturation at $95^{\circ} \mathrm{C}, 40$ cycles of $15 \mathrm{~s}$ at $95^{\circ} \mathrm{C}$ and $1 \mathrm{~min}$ at $60^{\circ} \mathrm{C}$ and a dissociation stage at the end of the run from 60 to $95^{\circ} \mathrm{C}$ with $0.3^{\circ} \mathrm{C}$ increments, and were carried out in a StepOnePlus ${ }^{\mathrm{TM}}$ Real-Time PCR system (Applied Biosystems). At least two replicates of each product to verify for accuracy and a nontemplate control to test for contamination of assay reagents were included in each experiment. The relative quantity of target, normalized to an endogenous control and relative to a reference sample, was calculated based on the threshold cycle $(\mathrm{Ct})$ value of $2^{-\Delta \Delta \mathrm{CT}}$ using StepOne ${ }^{\text {TM }}$ software (ver. 2.3).

\section{Immunophenotypic analysis of bovine macrophages} incubated with PLGA NP preparations

For a 24 -h period prior to collection, $1 \times 10^{6} \mathrm{MoM} \Phi$ in $1 \mathrm{ml}$ were incubated with PBS, $50 \mathrm{mg} \mathrm{l}^{-1}$ of PLGA/ MPLA NPs and $50 \mu \mathrm{g} \mathrm{ml}^{-1}$ PLGA/MPLA/MAP2322c NP in individual standard wells of a 12-well plastic culture plate. Three to four wells were assigned to each of the aforementioned study groups. The macrophages treated with PBS were utilized as a control. The cells were collected using a sterile cell scraper, and gently washed using PBS at $37^{\circ} \mathrm{C}$. For phenotypic maturation studies, the MoM $\Phi$ of each group were separately incubated with $15 \mathrm{mg} \mathrm{l}^{-1}$ of COLIS69A (Mab isotype control with specificity for $E$. coli J5), major histocompatibility complex (MHC) I (clone H6A) and MHC II (clone CAT82A), followed by incubation with a fluorescein-conjugated IgG/ IgM antibody. All Mabs were obtained from the Washington State University Monoclonal Antibody Center, Pullman, WA. Samples were acquired on a Becton Dickinson FACSCalibur (BD Biosciences, Franklin Lakes, NJ) by gating on the live cell populations. All non-CD $14^{+}$ populations were excluded. The data were further evaluated using FCS Express 4 (DeNovo Software) and presented as dot plots.

\section{CD4T Cell proliferation assay}

Blood was collected from calf $48432\left(\mathrm{DRB}^{\star} 1101{ }^{\star} 1401\right)$ that was previously immunized four times subcutaneously at 3-week intervals with $60 \mu \mathrm{g}$ of purified A. marginale St. Maries strain OMs (Lopez et al. 2005) emulsified in $6 \mathrm{mg}$ of saponin diluted in $1.3 \mathrm{ml}$ PBS. PBMC were purified from blood samples by Histopaque gradient centrifugation, repeatedly washed with Hanks' buffered salt solution (ThermoFisher Scientific, Waltham, MA), suspended in RPMI 1640 medium (Sigma-Aldrich) supplemented with $10 \%$ FBS, $100 \mathrm{mmol} \mathrm{l}^{-1}$ L-glutamine, $50 \mathrm{~mol} \mathrm{l}^{-1}$ 2-ME, $24 \mathrm{mmmol} \mathrm{l}^{-1}$ HEPES buffer, and $50 \mathrm{mg} \mathrm{l}^{-1}$ gentamycin sulphate (complete RPMI; cRPMI). To establish 2-week T-cell lines, $4 \times 10^{6} \mathrm{PBMC}$ were cultured in $1.5 \mathrm{ml}$ cRPMI with $1 \mathrm{mg} \mathrm{l}^{-1}$ A. marginale $\mathrm{OM}$ in 24-well plates and incubated in $5 \% \mathrm{CO}_{2}$ at 
$37^{\circ} \mathrm{C}$ for 1 week allowing an enrichment of OM-specific $\mathrm{T}$ cells. T cells were collected, washed and resuspended in cRPMI, and cultured in 24 -well plates at $7 \times 10^{5}$ cells per well with $2 \times 10^{6}$ cells per well of irradiated $(3000$ rads) autologous PBMC as a source of APC without antigen (rested) for 1 week in $5 \% \mathrm{CO}_{2}$ at $37^{\circ} \mathrm{C}$. Cells were then centrifuged, washed, and resuspended in cRPMI. $3 \times 10^{4} \mathrm{~T}$ cells and $2 \times 10^{5}$ irradiated PBMC were cultured in a total volume of $100 \mu \mathrm{l}$ in 96-well round-bottomed plates. Anaplasma marginale OM-derived peptides VirB9-1 P8 (negative control) and VirB9-2 P5 were tested at $1 \mathrm{mg} \mathrm{l}^{-1}$ and $10 \mathrm{mg} \mathrm{l}^{-1}$. NP formulations PLGA/ MPLA (control), PLGA/MPLA/VirB9-1 P8, and PLGA/ MPLA/VirB9-2 P5 were tested at 5 and $25 \mathrm{mg} \mathrm{l}^{-1} \mathrm{NP}$. For all assays, cells with medium only served as a negative control and cells with 10\% T-cell growth factor (TCGF) served as a positive control. Cells were incubated in $5 \% \quad \mathrm{CO}_{2}$ at $37^{\circ} \mathrm{C}$ for 3 days, radiolabelled with $0.25 \mu \mathrm{Ci} 3 \mathrm{H}$-thymidine per well and incubated an additional $18 \mathrm{~h}$ before harvesting with a Tomtec Harvester96 and quantifying with a PerkinElmer 1450 TriLux MicroBeta liquid scintillation counter (Waltham, MA, USA). Results are presented as the Stimulation Index, calculated as the mean CPM of cells cultured with antigen/ mean CPM of cells cultured with medium.

\section{Statistical analysis}

The experiments were run in biological triplicates. A twotailed paired $t$-test was used to compare two data. Values of $P<0.05$ were considered statistically significant.

\section{Results}

\section{Characterization of PLGA NP formulations}

Physical-chemical characterization, including hydrodynamic diameter, zeta potential, Polydispersity Index, mobility, conductivity and encapsulating efficiency (EE) of peptides and MPLA, of the several PLGA NPs constructs used in this study are summarized in Table 1. The mean diameters of PLGA varied from 431 to $1218 \mathrm{~nm}$. Zeta potential showed negative values for all NP preparations $(-8.58$ to $-14.8 \mathrm{mV})$. PLGA/MPLA NP showed reduced overall surface negativity except for PLGA/MPLA/MAP2322c. The results described herein suggest negligible differences among the PLGA NPs preparations used in this study. The EE for the PLGA NPs preparation varied from approximately 50-100\%. Higher EE were also obtained for preparation containing MPLA with exception of the PLGA/MPLA/MAP2322c. SEM of the PLGA/MPLA/Map peptide and Ova NPs showed that the NPs were spherical, presenting with smooth surface with absence of superficial irregularities containing an electron dense core when peptides were present. A representative example is shown in Fig. 1a,b. The in vitro release of PLGA/MPLA/MAP0981c and PLGA/MPLA/Ova NP in PBS at $37^{\circ} \mathrm{C}$ was evaluated over 4 weeks. Results indicated that $\sim 30 \%$ of MAP0981c is released from PLGA/MPLA NPs during the first week reaching at maximum a released profile of $\sim 60 \%$ after 4 weeks (data not shown). The obtained results were in agreement with those previously reported in the literature for the same PLGA NPs under similar conditions (Sarti et al. 2011; Danhier et al. 2012; Guldner et al. 2016a).

\section{PLGA NP uptake by bovine macrophages}

Uptake of the PLGA NP preparations by bovine MoMФ was evaluated by flow cytometry, confocal microscopy and TEM. Only PLGA/MPLA preparations containing OVA-FITC were used for the confocal and flow cytometry experiments. Bovine MoM $\Phi$ were incubated with PLGA/MPLA/OVA-FITC for $24 \mathrm{~h}$ and mean fluorescent intensity (MFI) of FITC was measured by flow cytometry against macrophages incubated with PBS or OVA-FITC (i.e. positive control). Results showed that PLGA/MPLA NPs were efficiently internalized by $\operatorname{MoM} \Phi$ (Fig. 2g,h). These observations were consistent with previous studies performed on the ability of APCs to efficiently

Table 1 Properties of PLGA NPs constructs used in this study

\begin{tabular}{|c|c|c|c|c|c|c|c|}
\hline Formulation & $\begin{array}{l}\text { Hydrodynamic } \\
\text { diameter }(\mathrm{nm})\end{array}$ & $\begin{array}{l}\text { Zeta Potential } \\
(\mathrm{mV})\end{array}$ & $\begin{array}{l}\text { Polydispersity } \\
\text { Index }\end{array}$ & $\begin{array}{l}\text { Mobility } \\
\left(\mu \mathrm{m} \cdot \mathrm{cm} \mathrm{Vs}^{-1}\right)\end{array}$ & $\begin{array}{l}\text { Conductivity } \\
\left(\mathrm{mS} \mathrm{cm}^{-1}\right)\end{array}$ & $\begin{array}{l}\text { Protein } \\
\text { EE (\%) }\end{array}$ & $\begin{array}{l}\text { MPLA } \\
\text { EE (\%) }\end{array}$ \\
\hline PLGA & $431 S D \pm 162$ & -14.8 & $0 \cdot 141$ & $-1 \cdot 159$ & 18 & - & - \\
\hline PLGA/OVA & $658.1 S D \pm 273.7$ & $-11 \cdot 3$ & 0.518 & -0.885 & 19 & 100 & - \\
\hline PLGA/MPLA & $400 S D \pm 125$ & -8.58 & 0.947 & -0.672 & 18 & - & 98.41 \\
\hline PLGA/MPLA/OVA & $566 \cdot 7 \mathrm{SD} \pm 339 \cdot 3$ & -9.41 & 0.358 & -0.737 & 18 & $90 \cdot 8$ & $97 \cdot 34$ \\
\hline PLGA/MPLA/0981C & $1218 S D \pm 118$ & -8.58 & 0.947 & -0.672 & 18 & $108 \cdot 5$ & 68.9 \\
\hline PLGA/MPLA/2322c & $764.7 S D \pm 628.5$ & -11.4 & 0.675 & -0.896 & 18 & $50 \cdot 13$ & $37 \cdot 2$ \\
\hline
\end{tabular}

EE, encapsulation efficiency; PLGA, poly (lactic-co-glycolic acid); MPLA, monophosphoryl lipid A; OVA, ovalbumin; 0981c and 2322c, MAP recombinant peptides. 
(a)

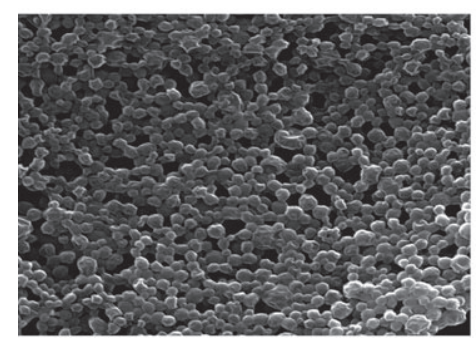

(b)

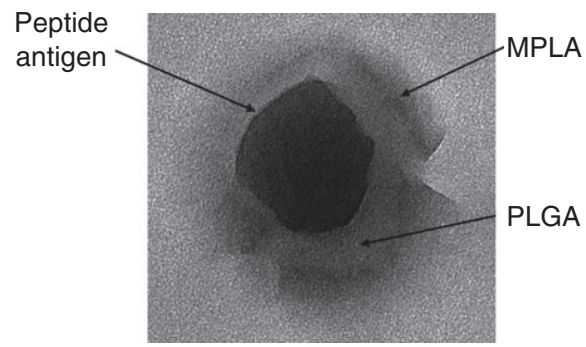

Figure 1 Morphological characterization of PLGA/MPLA NP. (a) Morphological analysis of PLGA/MPLA NP by scanning electron microscopy (SEM). (b) Transmission electron microscopy (TEM) of a single PLGA/MPLA/peptide NP. Scale bar $=1 \mu \mathrm{m}$ (a) and $100 \mathrm{~nm}$ (b). PLGA, poly lacticco-glycolic acid; MPLA, monophosphoryl lipid A.
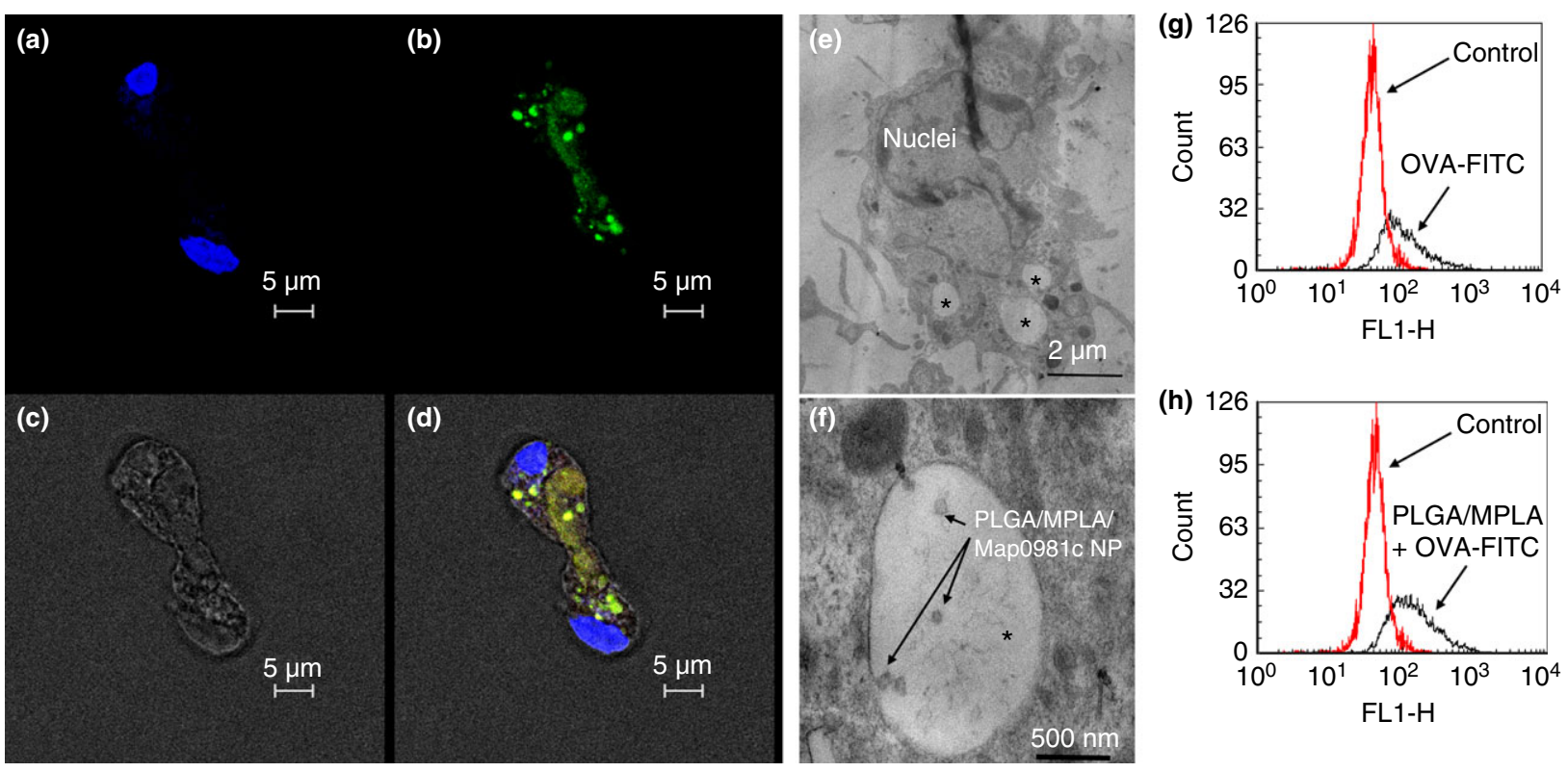

Figure 2 Cellular localization of PLGA/MPLA/OVA-FITC NPs uptake by macrophages and evaluated by confocal laser scanning microscopy after $2 \mathrm{~h}$ of incubation. Day 7 bovine MoM $\Phi$ cultures $\left(1 \times 10^{6}\right)$ were incubated with $50 \mathrm{mg} \mathrm{l}^{-1}$ of PLGA/MPLA/OVA-FITC NPs. After $24 \mathrm{~h}$, MoM $\Phi$ were harvested and analysed by confocal microscopy. One representative experiment is shown. (a) Nucleus of macrophages stain blue by DAPI. (b) PLGA/MPLA/OVA-FITC NPs stain green. (c) Bovine MoMФ observed by phase contrast microscopy. (d) Merge of (a) and (b) demonstrating internalization of NPs. Scale bar $=5 \mu \mathrm{m}$. DAPI $=4^{\prime}, 6$-diamidino-2-phenylindole, dihydrochloride; FITC, fluorescein isothiocyanate. Transmission electron microscopy (TEM) evaluation of cellular uptake of PLGA/MPLA NP preparations by bovine macrophages. Day 7 bovine MoM $\Phi$ cultures $\left(1 \times 10^{6}\right)$ were incubated with PBS or $50 \mathrm{mg} \mathrm{l}^{-1}$ of PLGA/MPLA/MAP0981c NPs. After $24 \mathrm{~h}$, nonadherent cells were harvested and analysed by TEM. (e, f) MoMФ incubated with PLGA/MPLA/Map0981c NPs for $24 \mathrm{~h}$ showing PLGA/MPLA NPs within phagocytic vacuoles $\left({ }^{*}\right)$. Flow cytometric evaluation of cellular uptake of PLGA NP preparations by bovine MoMФ. Flow cytometric analysis of MoMФ treated with PLGA/MPLA/OVA-FITC NPs. MoM $\Phi$ cultures $\left(1 \times 10^{6}\right)$ were incubated with $50 \mathrm{mg} \mathrm{l}^{-1}$ of PLGA/MPLAVOVA-FITC NP or OVA-FITC. After $24 \mathrm{~h}$, nonadherent cells were harvested and analysed by flow cytometry. One representative experiment is shown. (g) Mean fluorescence intensity (MFI) of MoM $\Phi$ incubated

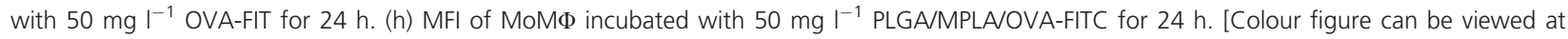
wileyonlinelibrary.com]

phagocytize PLGA NPs (Keijzer et al. 2011, 2013; Danhier et al. 2012). TEM studies demonstrated that MoMФ incubated with PLGA/MPLA NPs containing OVA or MAP0981c for $24 \mathrm{~h}$ displayed several electron dense intracytoplasmic structures compared to the control (i.e. PBS alone, data not shown), consistent with internalization of the PLGA NPs (Fig. 2e,f). In addition to flow cytometry and TEM, the cellular localization of PLGA NPs was assessed by confocal microscopy and showed efficient uptake of NPs (Fig. 2a-d). Comparable results were obtained when PLGA without MPLA NPs were used (data not shown), suggesting that MPLA had 
no effect on the ability of bovine MoMФ to phagocytize the PLGA NPs formulations used in this study.

\section{Macrophage viability studies}

MoMФ viability was evaluated by incubating 7-day-old bovine MoMФ with PLGA/MPLA, PLGA/MPLA/ MAP0981c and PLGA/MPLA/MAP2322c NPs for 2 or $24 \mathrm{~h}$. The results showed that there were no significant differences between the control groups and the several PLGA NPs tested at 2 or $24 \mathrm{~h}$ postincubation (Fig. 3a). In addition, cultures of MoM $\Phi$ incubated with different PLGA NPs constructs for $24 \mathrm{~h}$ and evaluated by light microscopy by a Board Certified Clinical Pathologist demonstrated absence of abnormal cytomorphological features consistent with cell death (i.e. apoptosis and necrosis; Fig. 3b). Lack of toxicity of PLGA NPs with or without MPLA to APCs was expected and corroborate with studies performed previously (Silva et al. 2015; Guldner et al. 2016a). Daily visual evaluation of the

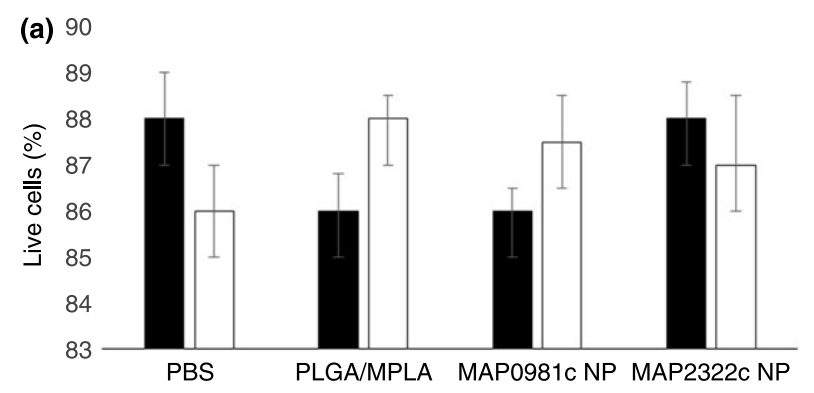

(b)

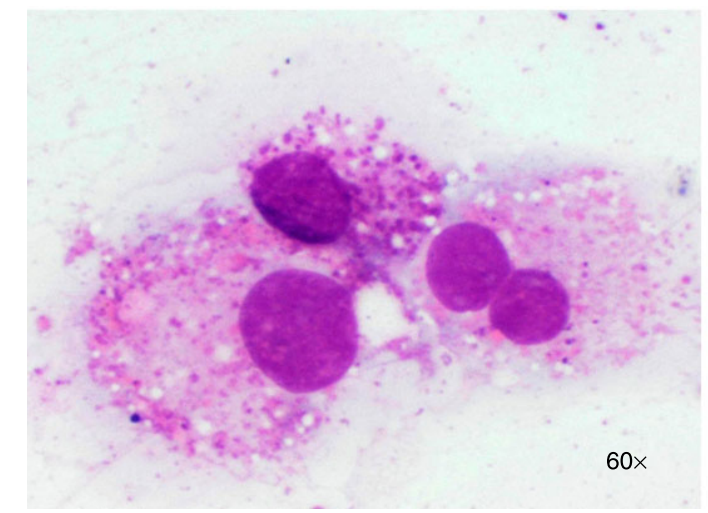

Figure 3 Evaluation of bovine macrophage viability incubated with PLGA NP formulations. Day 7 bovine MoM $\Phi$ cultures $\left(1 \times 10^{6}\right)$ were incubated with $50 \mathrm{mg} \mathrm{I}^{-1}$ of different PLGA NP formulations for $2 \mathrm{~h}$ or $24 \mathrm{~h}$ at $37^{\circ} \mathrm{C}$. MoM $\Phi$ were then stained with Trypan Blue and evaluated microscopically. (a) Cells that take the stain have impaired membranes and are considered dead cells. (b) A total of Day 7 $\left(1 \times 10^{6}\right)$ MoM $\Phi$ were cytocentrifuged and evaluated under light microscopy for evidence of pyknosis or cellular necrosis. Similar data were obtained in three independent experiments. [Colour figure can be viewed at wileyonlinelibrary.com]
MoMФ in culture for up to 5 days postviability analysis did not demonstrate cytomorphological changes that could be consistent with cell death. In addition, the RNA concentration and its quality also did not change throughout the set points we used for the experiments used on this study (data not shown).

\section{Cytokine expression}

Pro-inflammatory and pro-immune cytokine production by primed APCs are considered important components of an effective immune response and thus, essential in designing effective vaccines. In this study, pro-inflammatory (i.e. TNF $\alpha$ ), pro-immune (i.e. IL12p40) and anti-inflammatory (i.e. IL10) cytokine expression were measured to evaluate the potential of PLGA NP preparations to induce early, protective, immune responses initiated by $M \circ M \Phi$. Bovine $\operatorname{MoM} \Phi$ were incubated with different PLGA NP constructs and the expression of the above cytokines was determined at different time points (Fig. 4). As expected, incubation of MoMФ with PLGA NPs containing MPLA (i.e. LPS derivative), upregulated $\mathrm{TNF} \alpha$ expression at all time points in this study. Increases of more than 10-fold compared to control were observed. The results also showed that PLGA/MPLA with or without addition of MAP0981c or MAP2322c upregulated $\mathrm{TNF} \alpha$ at comparative levels as bacterial LPS at early time points. Surprisingly, this increase was significantly higher than the one elicited by LPS at later time points, particularly when Map antigens were included in the formulations (Fig. 4a). Similar increases were seen with IL12p40 expression at all time points studied when macrophages were incubated with LPS or PLGA NPs preparations with or without addition of MAP0981c or MAP2322c (Fig. 4b). Importantly, expression of IL10 did not appear to be significantly induced at later time points by incubation of MoM $\Phi$ with any of the PLGA NP formulations used in this study (Fig. 4c).

\section{Analysis of MHC I and MHC II expression}

Seven-day-old MoMФ were stimulated with empty PLGA/MPLA NP or PLGA/MPLA/MAP0981c NPs for $24 \mathrm{~h}$ and thereafter cells were evaluated by flow cytometry. Results showed no difference in the expression of MHC I or II by bovine MoMФ stimulated with the above PLGA NPs (data not shown).

\section{T-cell stimulation assay}

As a proof of concept, to show that the PLGA/MPLA NPs loaded with antigen could stimulate CD4 T cells, we used $\mathrm{T}$ cells from a calf that had been previously 
(a)

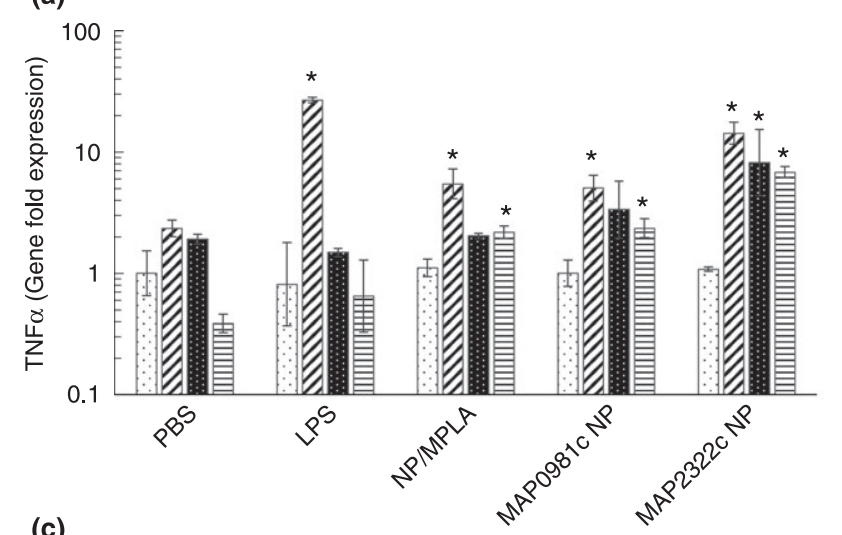

(c)

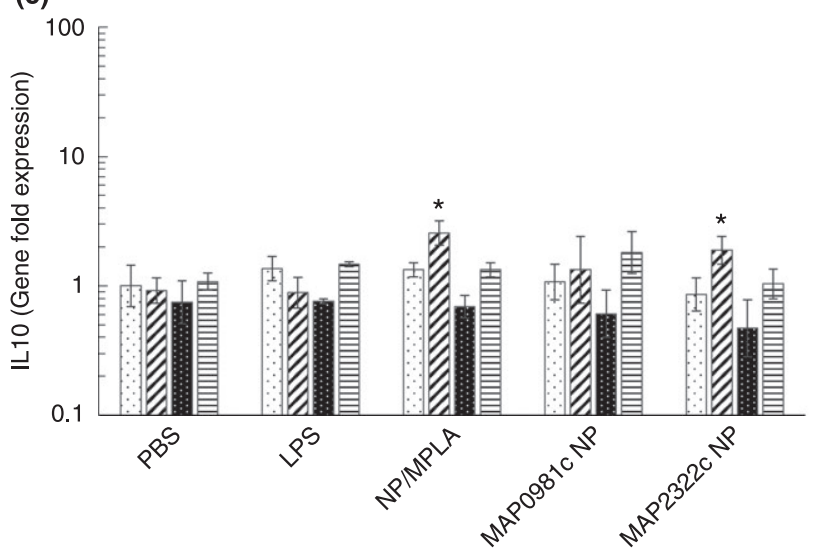

(b)

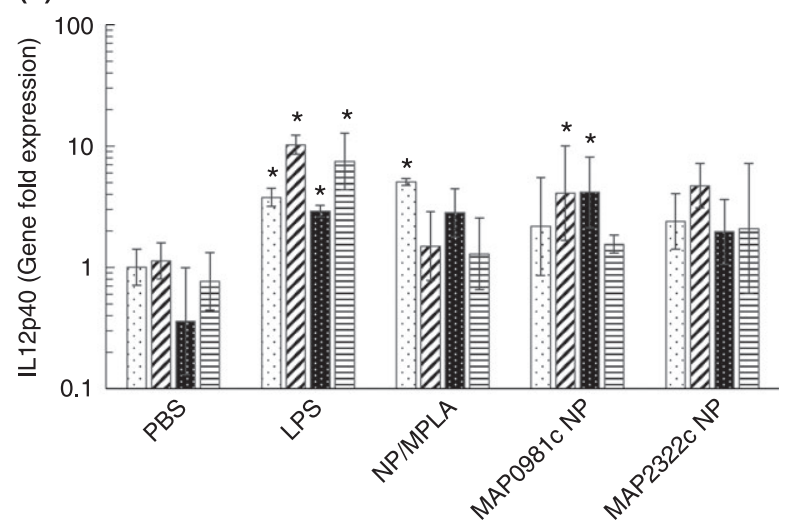

Figure 4 Effects of incubation of PLGA NP preparations on TNF $\alpha$ (a), IL12p40 (b) and IL10 (c), gene expression by bovine MoM $\Phi$. Day 7 MoM $\Phi$ $\left(1 \times 10^{6}\right.$ per $\left.\mathrm{mL}\right)$ were pretreated with $50 \mathrm{mg} \mathrm{I}^{-1}$ of PLGA/MPLA NP, PLGA/MPLA/MAP0981c NP, PLGA/MPLA/MAP2322c NP or LPS (1 mg I-1) for $0,24,48$ or $72 \mathrm{~h}$. GAPDH was used to normalize the results. *Statistically significant difference when compared to PBS and PLGA/MPLA NPtreated group $(P<0.05)$. Similar data were obtained in three independent experiments. 0 h; 1 day; 3 day; 目 5 day.

immunized with A. marginale OM expressing MHC II DRB3 haplotype ${ }^{\star} 1101$, which was shown to respond to peptide 5 of VirB9-2, but not peptide 8 of VirB9-1 (Morse et al. 2012). PLGA/MPLA NP were loaded with each peptide (as described above) and tested with free peptide in a proliferation assay using a short-term T-cell line, started from PBMC stimulated with OM for 1 week and rested with APC without antigen for 1 week. The cell line responded specifically and significantly to VirB9-2 P5, but not VirB9-1 P8 as predicted (Fig. 5). Importantly, the $\mathrm{T}$ cells also responded specifically and significantly to PLGA NPs loaded with VirB9-2 P5, but not with VirB9-1 P8 or empty PLGA/MPLA NPs. The response to VirB9-2 P5-loaded PLGA/MPLA NP was lower than the response to free peptide VirB9-2 P5 as there is an estimated 10fold less peptide present in the PLGA NPs formulation.

\section{Discussion}

The objective of the present study was to evaluate the potential of PLGA/MPLA NPs, as a vector system, for delivery of candidate peptide-based vaccines for Paratuberculosis. Initial studies showed a modified double emulsion solvent evaporation technique was the most efficient method to prepare PLGA/MPLA NPs (Danhier et al. 2012; Guldner et al. 2016a). Physicochemical analysis of the PLGA/MPLA NP constructs in solution demonstrated that NPs in solution were dispersed with limited aggregation of particles. Examination by SEM showed that PLGA NPs had a smooth regular surface in a size range optimal for uptake by MoMФ (Table 1) similar to the size ranges observed in other studies (Elamanchili et al. 2007; Kanchan and Panda 2007; Guldner et al. 2016b). Examination by TEM showed the PLGA/MPLA NPs containing peptides were comprised of an outer ring of MPLA and an inner ring of PLGA with a dense peptide central core. Phagocytosis and viability studies showed the PLGA NPs and PLGA/MPLA NPs were taken up rapidly and efficiently with no evidence of cytotoxicity at the concentrations used in the studies. Similar to previous reports, phagocytosis of the PLGA/MPLA NPs increased the expression of TNF $\alpha$ and IL12p40. Flow 


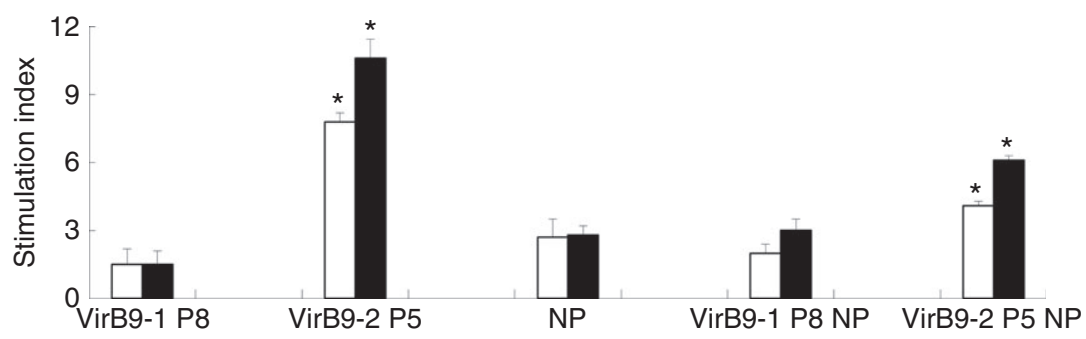

Figure 5 PLGA/MPLA NP loaded with Anaplasma marginale outer membrane antigen-stimulated CD4 T cells. Anaplasma marginale-immune T cells were washed, and cultured at $3 \times 10^{4}$ cells per well in triplicate with $2 \times 10^{5}$ irradiated, autologous PBMC as a source of APC. Free peptide (VirB9-1 P8 and VirB9-2 P5) were tested at 1 and $10 \mathrm{mg} \mathrm{I}^{-1}$ and PLGA/MPLA NP formulations were tested at 5 and 25 mg I I $^{-1}$ of PLGA NP. White bars and black bars represent low and high antigen concentration respectively. *VirB9-2 P5 and PLGA/MPLANirB9-2 P5 NP stimulated significant responses compared to VirB9-1 P8, or empty PLGA/MPLA NP or PLGA/MPLANirB9-1 P8 NP, respectively, at both antigen concentrations, where $P<0.05$ using a Student's $t$-test.

cytometric analysis of the level of expression of MHC I and II molecules showed there was no clear change in the level of expression of MHC I or MHC II molecules following uptake of PLGA/MPLA NPs with and without inclusion of peptides (data not shown).

The last set of experiments were conducted for proof of concept to show whether antigenic peptides processed and presented by $M \circ M \Phi$, pulsed with a peptide-containing PLGA/MPLA NPs can elicit a recall response ex vivo. Ongoing studies of the immune response to A. marginale with a steer (DRB3 haplotype ${ }^{*} 1101$ ) had shown that a MHC II-restricted response could be elicited to peptide 5 of VirB9-2, encoding an epitope recognized by CD4 T cells. This afforded an unique opportunity to examine the functionality of $M o M \Phi$ in a genetically defined context with a source of autologous cells where experiments could be duplicated as needed (Morse et al. 2012). A control peptide, peptide 8 of the VirB9-1 protein had been identified which is not recognized by the MHC II allomorph expressed by the DRB3 haplotype ${ }^{\star} 1101$. Three repeats of the experiment with a CD4 T-cell line specific for peptide 5 of VirB9-2 demonstrated that MoMФ pulsed with encapsulated peptide 5 consistently elicited a MHC II restricted immune response (Fig. 5).

The results obtained in the present study paves the way for use of PLGA/MPLA NP technology to investigate methods for modulating the functional activity of APC by targeting the PRRs that initiate signalling cascades that drive $\mathrm{T}$ cell differentiation. The PLGA NPs have been shown to be safe for use in vivo (Chong et al. 2005; Hamdy et al. 2011; Silva et al. 2015; Guldner et al. 2016b). The present results support they can also be used ex vivo, expanding opportunities for further studies of Anaplasmosis and especially for ongoing studies focused on developing a peptide-based vaccine for Paratuberculosis. Ex vivo studies with monocytederived dendritic cells (MoDC) and MoMФ have shown $\mathrm{MoDC}$ and $\mathrm{MoM} \Phi$ pulsed with a relA deletion mutant elicit a MHC-restricted recall response with PBMC from a steer vaccinated with the mutant (Park et al. 2016). Analysis of the response has shown both CD4 and CD8 T cells proliferate in response to antigens processed and presented to PBMC by MoDC and MoMФ. Of considerable interest, part of the response is directed to another Map peptide under consideration for inclusion in a peptide-based vaccine, a major membrane protein (MMP) (Bannantine et al. 2003). Preliminary studies comparing the proliferative response to MMP alone and encapsulated in PLGA/MPLA have shown that MoDC pulsed with PLGA/MPLA/MMP NP elicit a more vigorous response than MoDC pulsed with MMP alone (C. Souza et al. unpublished).

The need for more safe and effective vaccines has stimulated the development of new vaccine technologies. These include delivery systems and adjuvants to target the innate immune system to provide a stimulus that potentiates the development of antigen-specific immune responses. Delivery systems based on PLGA containing the immunomodulatory molecule MPLA has been shown to be safe and able to elicit optimal immune responses. Moreover, they can be administered by several routes, which offer the possibility of developing both mucosal and systemic immune responses. Our preliminary studies in bovine set the stage for more in depth studies on NP delivery systems in a setting that may lead to the development of a peptide-based vaccine for economically important diseases of cattle. It will be possible to conduct studies to detail how the delivery of antigens to specific PRRs with PLGA/MPLA NPs modulate the signalling cascades in APC that drive T-cell differentiation. In addition, it will be possible to identify the peptide sequences presented by MHC I as well as MHC II molecules involved in T-cell activation and differentiation.

\section{Acknowledgements}

This research was supported in part by an intramural grant (\#9830) from Washington State University College of Veterinary Medicine. 


\section{Conflict of Interest}

The authors declare no conflict of interest on any of data published in this manuscript.

\section{References}

Bannantine, J.P. and Talaat, A.M. (2015) Controlling Johne's disease: vaccination is the way forward. Front Cell Infect Mi 5, 2.

Bannantine, J.P., Huntley, J.F., Miltner, E., Stabel, J.R. and Bermudez, L.E. (2003) The Mycobacterium avium subsp. paratuberculosis $35 \mathrm{kDa}$ protein plays a role in invasion of bovine epithelial cells. Microbiology 149, 2061-2069.

Bannantine, J.P., Stabel, J.R., Bayles, D.O. and Geisbrecht, B.V. (2010) Characteristics of an extensive Mycobacterium avium subspecies paratuberculosis recombinant protein set. Protein Expres Purif 72, 223-233.

Bannantine, J.P., Hines, M.E., Bermudez, L.E., Talaat, A.M., Sreevatsan, S., Stabel, J.R., Chang, Y.F., Coussens, P.M. et al. (2014) A rational framework for evaluating the next generation of vaccines against Mycobacterium avium subspecies paratuberculosis. Front Cell Infect Mi 4, 126.

Bannantine, J.P., Stabel, J.R., Laws, E., MC, D.C. and Souza, C.D. (2015) Mycobacterium avium subspecies paratuberculosis recombinant proteins modulate antimycobacterial functions of bovine macrophages. PLoS ONE 10, e0128966.

Bowdish, D.M.E., Sakamoto, K., Kim, M.J., Kroos, M., Mukhopadhyay, S., Leifer, C.A., Tryggvason, K., Gordon, S. et al. (2009) MARCO, TLR2, and CD14 are required for macrophage cytokine responses to mycobacterial trehalose dimycolate and Mycobacterium tuberculosis. PLoS Pathog 5, e1000474.

Chen, J.W., Faisal, S.M., Chandra, S., McDonough, S.P., Moreira, M.A.S., Scaria, J., Chang, C.F., Bannantine, J.P. et al. (2012) Immunogenicity and protective efficacy of the Mycobacterium avium subsp paratuberculosis attenuated mutants against challenge in a mouse model. Vaccine 30, 3015-3025.

Chong, C.S.W., Cao, M., Wong, W.W., Fischer, K.P., Addison, W.R., Kwon, G.S., Tyrrell, D.L. and Samuel, J. (2005) Enhancement of $\mathrm{T}$ helper type 1 immune responses against hepatitis $\mathrm{B}$ virus core antigen by PLGA nanoparticle vaccine delivery. J Control Release 102, 85-99.

Conway, M.A., Madrigal-Estebas, L., McClean, S., Brayden, D.J. and Mills, K.H.G. (2001) Protection against Bordetella pertussis infection following parenteral or oral immunization with antigens entrapped in biodegradable particles: effect of formulation and route of immunization on induction of Th1 and Th2 cells. Vaccine 19, 1940-1950.

Cui, W.G., Joshi, N.S., Liu, Y., Meng, H.L., Kleinstein, S.H. and Kaech, S.M. (2014) TLR4 ligands lipopolysaccharide and monophosphoryl lipid a differentially regulate effector and memory CD8(+) T cell differentiation. J Immunol 192, 4221-4232.

Danhier, F., Ansorena, E., Silva, J.M., Coco, R., Le Breton, A. and Preat, V. (2012) PLGA-based nanoparticles: an overview of biomedical applications. J Control Release 161, 505-522.

Elamanchili, P., Lutsiak, C.M.E., Hamdy, S., Diwan, M. and Samuel, J. (2007) "Pathogen-mimicking" nanoparticles for vaccine delivery to dendritic cells. J Immunother 30, 378395.

Eldridge, J.H., Staas, J.K., Tice, T.R. and Gilley, R.M. (1992) Biodegradable poly(DL-lactide-co-glycolide) microspheres. Res Immunol 143, 557-563.

Fichter, M., Dedters, M., Pietrzak-Nguyen, A., Pretsch, L., Meyer, C.U., Strand, S., Zepp, F., Baier, G. et al. (2015) Monophosphoryl lipid A coating of hydroxyethyl starch nanocapsules drastically increases uptake and maturation by dendritic cells while minimizing the adjuvant dosage. Vaccine 33, 838-846.

Griffin, J.F.T., Hughes, A.D., Liggett, S., Farquhar, P.A., Mackintosh, C.G. and Bakker, D. (2009) Efficacy of novel lipid-formulated whole bacterial cell vaccines against Mycobacterium avium subsp paratuberculosis in sheep. Vaccine 27, 911-918.

Guldner, D., Hwang, J.K., Cardieri, M.C., Eren, M., Ziaei, P., Norton, M.G. and Souza, C.D. (2016a) In vitro evaluation of the biological responses of canine macrophages challenged with PLGA nanoparticles containing monophosphoryl lipid A. PLoS ONE 11, e0165477.

Guldner, D., Hwang, J.K., Cardieri, M.C.D., Eren, M., Ziaei, P., Norton, M.G. and Souza, C.D. (2016b) In vitro evaluation of the biological responses of canine macrophages challenged with PLGA nanoparticles containing monophosphoryl lipid A. PLoS ONE 11, e0165477.

Hamdy, S., Haddadi, A., Hung, R.W. and Lavasanifar, A. (2011) Targeting dendritic cells with nano-particulate PLGA cancer vaccine formulations. Adv Drug Deliver Rev 63, 943-955.

Harris, N.B. and Barletta, R.G. (2001) Mycobacterium avium subsp paratuberculosis in veterinary medicine. Clin Microbiol Rev 14, 489-512.

Kanchan, V. and Panda, A.K. (2007) Interactions of antigenloaded polylactide particles with macrophages and their correlation with the immune response. Biomaterials 28, 5344-5357.

Kathaperumal, K., Park, S.U., McDonough, S., Stehman, S., Akey, B., Huntley, J., Wong, S., Chang, C.F. et al. (2008) Vaccination with recombinant Mycobacterium avium subsp. paratuberculosis proteins induces differential immune responses and protects calves against infection by oral challenge. Vaccine 26, 1652-1663.

Kathaperumal, K., Kumanan, V., McDonough, S., Chen, L.H., Park, S.U., Moreira, M.A., Akey, B., Huntley, J. et al. (2009) Evaluation of immune responses and protective efficacy in a goat model following immunization with a 
coctail of recombinant antigens and a polyprotein of Mycobacterium avium subsp. paratuberculosis. Vaccine 27, 123-135.

Keijzer, C., Slutter, B., van der Zee, R., Jiskoot, W., van Eden, W. and Broere, F. (2011) PLGA, PLGA-TMC and TMCTPP nanoparticles differentially modulate the outcome of nasal vaccination by inducing tolerance or enhancing humoral immunity. PLoS ONE 6, e26684.

Keijzer, C., Spiering, R., Silva, A.L., van Eden, W., Jiskoot, W., Vervelde, L. and Broere, F. (2013) PLGA nanoparticles enhance the expression of retinaldehyde dehydrogenase enzymes in dendritic cells and induce FoxP3(+) T-cells in vitro. $J$ Control Release 168, 35-40.

Klippstein, R. and Pozo, D. (2010) Nanotechnology-based manipulation of dendritic cells for enhanced immunotherapy strategies. Nanomed-Nanotechnol 6, 523-529.

Kormendy, B. (1994) The effect of vaccination on the prevalence of paratuberculosis in large dairy herds. Vet Microbiol 41, 117-125.

Lopez, J.E., Siems, W.F., Palmer, G.H., Brayton, K.A., McGuire, T.C., Norimine, J. and Brown, W.C. (2005) Identification of novel antigenic proteins in a complex Anaplasma marginale outer membrane immunogen by mass spectrometry and genomic mapping. Infect Immun 73, 8109-8118.

Morse, K., Norimine, J., Hope, J.C. and Brown, W.C. (2012) Breadth of the CD4+ T cell response to Anaplasma marginale VirB9-1, VirB9-2 and VirB10 and MHC class II DR and DQ restriction elements. Immunogenetics 64, 507523.

Noss, E.H., Pai, R.K., Sellati, T.J., Radolf, J.D., Belisle, J., Golenbock, D.T., Boom, W.H. and Harding, C.V. (2001) Toll-like receptor 2-dependent inhibition of macrophage class II MHC expression and antigen processing by 19$\mathrm{kDa}$ lipoprotein of Mycobacterium tuberculosis. J Immunol 167, 910-918.

Park, K.T., Allen, A.J., Barrington, G.M. and Davis, W.C. (2014) Deletion of relA abrogates the capacity of Mycobacterium avium paratuberculosis to establish an infection in calves. Front Cell Infect Microbiol 4, 64.

Park, K.T., ElNaggar, M.M., Abdellrazeq, G.S., Bannantine, J.P., Mack, V., Fry, L.M. and Davis, W.C. (2016) Phenotype and function of CD209+ bovine blood dendritic cells, monocyte-derived-dendritic cells and monocyte-derived macrophages. PLoS ONE 11, e0165247.

Reddacliff, L., Eppleston, J., Windsor, P., Whittington, R. and Jones, S. (2006) Efficacy of a killed vaccine for the control of paratuberculosis in Australian sheep flocks. Vet Microbiol 115, 77-90.

Rigden, R.C., Jandhyala, D.M., Dupont, C., Crosbie-Caird, D., Lopez-Villalobos, N., Maeda, N., Gicque, B. and Murray, A. (2006) Humoral and cellular immune responses in sheep immunized with a 22 kilodalton exported protein of Mycobacterium avium subspecies paratuberculosis. J Med Microbiol 55, 1735-1740.

Roupie, V., Leroy, B., Rosseels, V., Piersoel, V., Noel-Georis, I., Romano, M., Govaerts, M., Letesson, J.J. et al. (2008) Immunogenicity and protective efficacy of DNA vaccines encoding MAP0586c and MAP4308c of Mycobacterium avium subsp paratuberculosis secretome. Vaccine $\mathbf{2 6}$, 4783-4794.

Sarti, F., Perera, G., Hintzen, F., Kotti, K., Karageorgiou, V., Kammona, O., Kiparissides, C. and Bernkop-Schnurch, A. (2011) In vivo evidence of oral vaccination with PLGA nanoparticles containing the immunostimulant monophosphoryl lipid A. Biomaterials 32, 4052-4057.

Settles, E.W., Kink, J.A. and Talaat, A. (2014) Attenuated strains of Mycobacterium avium subspecies paratuberculosis as vaccine candidates against Johne's disease. Vaccine 32, 2062-2069.

Silva, A.L., Rosalia, R.A., Varypataki, E., Sibuea, S., Ossendorp, F. and Jiskoot, W. (2015) Poly-(lactic-co-glycolic-acid)based particulate vaccines: particle uptake by dendritic cells is a key parameter for immune activation. Vaccine 33, 847-854.

Souza, C.D. (2015) Blocking the mitogen activated protein kinase-p38 pathway is associated with increase expression of nitric oxide synthase and higher production of nitric oxide by bovine macrophages infected with Mycobacterium avium subsp paratuberculosis. Vet Immunol Immunopathol 164, 1-9.

Souza, C., Davis, W.C., Eckstein, T.M., Sreevatsan, S. and Weiss, D.J. (2013) Mannosylated lipoarabinomannans from Mycobacterium avium subsp paratuberculosis alters the inflammatory response by bovine macrophages and suppresses killing of Mycobacterium avium subsp avium organisms. PLOS ONE 8, e75924.

Stringer, L.A., Wilson, P.R., Heuer, C., Hunnam, J.C. and Mackintosh, C.G. (2011) Effect of vaccination and natural infection with Mycobacterium avium subsp paratuberculosis on specificity of diagnostic tests for bovine tuberculosis in farmed red deer (Cervus elaphus). New Zeal Vet J 59, 218-224.

Ulrich, J.T. and Myers, K.R. (1995) Monophosphoryl lipid A as an adjuvant. Past experiences and new directions. Pharm Biotechnol 6, 495-524.

Wang, D.B. (2013) Monophosphoryl lipid A is an lipopolysaccharide-derived toll-like receptor 4 agonist which may improve Alzheimer's disease pathology. Expert Opin Biol Th 13, 1639-1641.

Wentink, G.H., Bongers, J.H., Zeeuwen, A.A.P.A. and Jaartsveld, F.H.J. (1994) Incidence of paratuberculosis after vaccination against mycobacterium-paratuberculosis in 2 infected dairy herds. J Vet Med B 41, 517-522. 